поширеною і актуальною в сучасному суспільстві. Результати дослідження моделі польської освітньої системи дають змогу констатувати, що під час розроблення стратегії розвитку вищої освіти в Україні особливо пізнавальним є досвід сусідньої Польщі.

Перспективи подальших досліджень полягають у вивченні потенційних можливостей українсько-польської співпраці у професійній підготовці фахівців різного профілю.

1. Андрушкевич Ф. Польський «освітній прорив» та його значення для українських освітніх інновацій / Ф. Андрушкевич // Вища освіта в Україні. - 2010. № 4. - С. 103-108. 2. Міжнародні програми навчання за кордоном [Електронний pecypc] - Режим доступу: http://www.ksada.org/html/int3u.html 3. Общая справка о системе образования в Польше [Электронный ресурс]. - Режим доступу: http://www.educationsystems.info/item466.html 4. Програма розвитку вищої освіти України «Основні засади розвитку вищої освіти України в контексті Болонського процесу» / за редакцією В. Г. Кременя. упорядники: М. Ф. Степко, Я. Я. Болюбаш, В. Д. Шинкарук, В. В. Грубінко, І. І. Бабин / Київ - Тернопіль : Видавництво ТДПУ, 2004. - 147 c. 5. Савина А. К. Польша: международная тематика в содержании общего образования / А. К. Савина // Педагогика. - 2010. - № 2. - С. 94-99.

УДК 37.014 .3

Ірина Колесник

\title{
ІДЕЇ РЕФОРМУВАННЯ ОСВІТИ В ЗАХІДНІЙ СВРОПІ В ПЕРІОД ХІХ СТОЛІТТЯ
}

Колесник I. О. Ідеї реформування освіти в Західній Європі в період XIX століття.

У статті розкрито роль національних освітніх перетворень, визначено основні чинники розвитку педагогічної науки, глобальні тенденції розвитку освіти, характерні для країн Свропи й США досліджуваного періоду. Доведено, що реформування шкільної системи сприяло інтенсивному промисловому зростанню, розвитку педагогічної науки, а також відбиває потребу суспільства в підготовці через школу різнобічно розвинених, ініціативних людей, готових до активної діяльності в різних галузях економічного, політичної й громадського життя.

Ключові слова: держава, освіта, школа, гімназія, університет, реформування, розвиток, релігія.

Колесник И. А. Идеи реформирования образования в Западной Европе в период XIX века.

В статье раскрыта роль национальных преобразований, определены основные факторы развития педагогической науки, глобальные общие тенденции реформирования образования, характерные для стран Европы и США исследуемого периода. Доказано, что реформирование школьной системы способствовало интенсивному промышленному росту, развитию педагогической науки, а также отражает потребность общества в подготовке через школу разносторонне развитых, инициативных людей, готовых к активной деятельности в различных областях экономической, политической и общественной жизни. 
Ключевые слова: государство, образование, школа, гимназия, университет, реформирование, развитие, религия.

Kolesnik I. A. Ideas of reforming education in Western Europe during the XIX century.

The article deals with the role of national transformation, the basic factors of development of pedagogical science, global general trends of reforming education, typical for Europe and the United States the study period. It is proved that the reform of the school system promoted intensive industrial growth and development of pedagogical science, and also reflects the need of the society in the preparation through school versatile development, enterprising people willing to be active in various fields of economic, political and social life.

Key words: government, education, school, high school, university reform, development, religion.

Вивчення стану й динамічного розвитку західноєвропейських освітніх систем дозволяє стверджувати, що сучасний етап становить епоху глобального реформування освіти на світовому рівні. У рамках Болонського процесу відбувається уніфікація національних освітніх стандартів, диверсифікація освітніх моделей, удосконалення технологій навчання. Водночас кожна 3 націй прагне збагатити свій історично напрацьований освітній потенціал, активно вивчаючи інноваційний досвід організації і змісту освіти інших країн.

Аналіз стану розробки проблеми реформування шкільної освіти сучасними педагогами 3 різних боків (Б. Бим-Бад, М. Богуславський, Н. Вейкшан, С. Гессен, Л. Гончаров, М. Демков, Н. Латишев, С. Мендліна, К. Салімова, Дж. Боуэн, Є. Кей, У Коннелл, Л. Коул, У. Мак-Каллістер, Г. Рерс, Р. Уліч, К. Уошборн, Г. Штеккерт, Ж. Єльсландер та ін.) дає підстави засвідчити її надзвичайну актуальність.

Однак, на сьогодні не здійснено цілісного історико-педагогічного дослідження, в якому б в узагальненому вигляді було б відтворено досвід реформування освіти, розкрито генезу освітніх реформ згідно 3 динамікою розвитку освіти в період XIX століття.

Mema cmammi- проаналізувати основні напрямки i тенденції розвитку шкільної освіти в країнах Західної Свропи.

Аналіз історико-педагогічної літератури [1-5] дозволяє стверджувати, що в XIX ст. у педагогічній науці виникають теорії навчання й виховання, які стають класичними педагогічними теоріями для подальшого розвитку науки і практики освіти у всіх країнах світу.

У своєму дослідженні ми дотримуємось твердження А. Джуринського про те, що у всьому різноманітті педагогічних теорій і плинів розглянутого періоду можна виокремити два напрямки розвитку педагогічної думки: традиціоналістський, що $є$ продовженням класичної традиції, і реформаторський, що розробляє нові підходи [1]. До традиційних педагогічних теорій відносять соціальну, релігійну i філософську педагогіку. Реформаторська педагогіка (нове виховання) - це рух у педагогіці кінця XIX - початку XX в., що відображає потребу суспільства в підготовці через школу різнобічно розвинених, ініціативних людей, готових до активної діяльності в різних галузях економічного, політичного і громадського життя. Прихильники реформаторського руху вважали себе послідовниками ідей Ж.-Ж. Руссо, педагогічні ідеї просвітителя набули нового звучання й 
актуалізувалися в цю епоху. 3-поміж плинів нової педагогіки найбільш відомі вільне виховання, трудова школа, школа дії, прогресивне виховання тощо.

3-поміж плинів традиційної педагогіки найбільш відома соціальна педагогіка, одним з основоположників якої став Пауль Наторп (1854-1924), що розглядав навчання й виховання в широкому соціально-філософському контексті. У роботі «Соціальна педагогіка» він виокремив школу як найважливіший чинник соціалізації дитини, оскільки саме у школі створюється модель соціуму через співтовариство учителів і учнів. У межах соціальної педагогіки виховання й навчання у школі перетворюється на вироблення взаємин особистості й суспільства на основі єдності розуміння життєвих цінностей і норм. Із цією метою П. Наторп пропонує створити єдину для всіх верств населення школу, яка б уможливила усунення класових суперечностей.

Французький філософ, письменник Жан Поль Сартр (1905-1980) був представником екзистенціальної педагогіки - філософського напрямку педагогічної думки. Аналіз дитинства і його ролі у формуванні творчої особистості одержав відбиття в розробленому Сартром жанрі біографії (Г. Флобера й ін.), що інтегрує філософський, культурно-герменевтичний і соціально-історичний методи. Ідеалом особистості Ж. П. Сартр уважав вільну, одухотворену, мислячу людину й уважав, що вплив зовнішніх чинників на розвиток внутрішнього світу дитини $\epsilon$ мінімальним, отже, головним чинником виховання має стати самовиховання.

Реформаторська педагогіка була представлена більш широким спектром плинів і діячів, на ii розвиток потужний вплив зробив філософський плин позитивізму, основоположником якого став французький філософ Огюст Конт (1798-1857). Він визначав досвід і теоретичне знання як сукупність суб'єктивних відчуттів і переживань. Позитивісти в педагогіці стверджували, що характер педагогічного процесу переважно визначається спонтанним проявом схильностей дітей і тому задля ефективного й індивідуалізованого навчання необхідний пошук оптимальних засобів визначення задатків, схильностей та інтелектуального рівня розвитку кожної дитини, щоб допомогти їй обрати життєвий шлях.

У ході дослідження встановлено, що важливою тенденцією розвитку освіти Західної Європи і США в досліджуваний період було регулювання приватної ініціативи в освіті. У всіх шкільних системах Заходу тривала діяльність приватних навчальних закладів, які більшою чи меншою мірою контролювалися державними органами управління школою. Зокрема у Прусії відповідно до закону 1794 р. державному контролю підлягали всі без винятку школи незалежно від того, хто був їхнім засновником. У Франції законодавство гарантувало діяльність приватних шкіл, але при цьому функціонувала система їх міністерського інспектування. В Англії за законом 1870 р. уряд стимулював створення й діяльність приватних шкіл. У США приватні школи створювалися переважно релігійними конфесіями.

Вивчення історико-педагогічних джерел [1-5] довело, що у XIX ст. тривало відокремлення школи від церкви, що відбувалося неоднозначно у різних країнах. Так, найбільш суперечливий і напружений характер цей процес мав у Прусії. На початку XIX ст. законодавчо затвердився світський характер школи, до 1840-х рр. релігію було виключено з навчальних програм. Однак у 1846 р. церковна влада одержала право затверджувати на посаду шкільних учителів. Потім у 1848 р. світськість освіти була закріплена в Конституції, однак інша конституція 1850 р. закріпила в школі викладання релігії як обов'язкового навчального предмета. У підсумку до кінця сторіччя церковний вплив на школу залишався значним. В Англії 
державою декларувався необов'язковий характер навчання релігії, але в освітній практиці вона викладалася в кожній школі. У Франції, напроти, протягом усього XIX ст. йшов процес відокремлення школи від церкви. У США споконвічно державна й релігійна освіти розвивалися окремо.

Як свідчить проведене дослідження, національні системи освіти складалися як дуалістичні, тобто без зв'язку між масовою початковою школою й нечисленними середніми навчальними закладами. При цьому доступу до середньої школи перешкоджали висока оплата за навчання, непогодженість програм початкової й середньої школи, наявність особливих підготовчих класів. Задля розв'язання питань наступності початкової й середньої школи у XIX ст. виник новий тип школи - вища початкова школа, у якій до програми навчання, крім традиційних дисциплін, було внесено предмети природничо-наукового й реального циклів.

Зазначимо, що початкова освіта у більшості країн Західної Свропи й США в XIX ст. не зазнала значних змін. Головним досягненням було виникнення обов'язкової безкоштовної початкової освіти (строк навчання 7 років), окрім того, 3'явилися нові типи початкових шкіл, найпоширенішими 3 яких стали вечірні й недільні школи для навчання дорослих людей, що дозволило підвищити рівень грамотності населення. Навчання на початковому рівні організовувалося як роздільне для хлопчиків і дівчаток- у Європі й спільне - у США, було безкоштовним (або оплата за школу була незначною) і відповідало вимогам класноурочної системи [4].

У процесі наукового пошуку встановлено, що в більшості країн Західної Європи були деякі відмінності у змісті початкової освіти. Наприклад, в Англії до змісту програми початкової освіти було внесено читання, письмо, арифметику, малювання, рукоділля (для дівчаток); у Прусії - основи релігії, читання, письмо, арифметику, спів, початкові відомості 3 географії, історії, природознавства; у Франції - читання, письмо, правила рахування, уроки релігії, основи природознавства, географії, сільськогосподарської праці; у США - читання, письмо i арифметику.

Найбільші зміни в XIX ст. відбулися в середній освіті. Незважаючи на те, що навчальні заклади здебільшого зберегли традиційні назви, значно змінилися зміст освіти й організація навчання, майже повсюдно виникали реальні школи й училища. Ці перетворення відбувалися по-різному у провідних країнах Свропи і США. Так, в Англії середня освіта була представлена граматичними школами. 3-поміж них особливе поширення одержали «паблік скулз» (суспільні школи), які мали класичну спрямованість освіти й закритий характер навчання. У цих школах призначалася висока плата за навчання, виняток становили обдаровані діти з незаможних верств. Основними завданнями шкіл були формування лідерських якостей у вихованців, розвиток учнівського самоврядування, підготовка учнів до продовження освіти в елітарних Оксфордському і Кембриджському університетах. Випускниками «паблік скулз» стала переважна більшість англійських державних i політичних діячів, військових і дипломатичних лідерів і вищого духівництва. Програма навчання цих шкіл передбачала предмети класичної освіти, математику, природничо-наукові дисципліни, іноземні мови. Іншу частину граматичних шкіл становили тижневі школи двох напрямків: класичного й сучасного.

У Франції середня освіта була представлена ліцеями й коледжами. Програма освіти в них була однаковою, але перші фінансувалися державою, а другі муніципалітетами. Зміст освіти в них був класичним, а організація навчання 
залежала від послідовності вивчення дисциплін, у ліцеях і коледжах освіта тривала шість років, а по закінченні додаткової «філософської» освіти передбачався іспит на ступінь бакалавра.

У США провідним типом середньої школи стала академія, програма якої містила класичний і реальний компонент. У XIX ст. зміст освіти в академіях не був однаковим, оскільки це були приватні навчальні заклади. У другій половині сторіччя на базі початкової школи виникають державні середні школи - «хай скул», строк навчання в яких коливався від трьох до п'яти років, а програма поєднувала дисципліни елементарної й середньої освіти.

Результати дослідження засвідчують, що рубіж XIX і XX ст. ознаменувався новим рівнем розвитку промислових, суспільних й економічних відносин, що вимагав удосконалювання всіх галузей громадського життя й соціальноекономічних інститутів, у тому числі й виховання. Цього часу спостерігаються зростання суспільного інтересу до педагогіки й освіти, розвиток різних педагогічних теорій і систем, заснованих на нових і традиційних підходах до розуміння проблем навчання й виховання. У таких умовах цілком очевидно виявилася невідповідність тогочасної школи й суспільної практики рівню суспільного розвитку. Традиційна школа не сприяла розвитку в дітей самостійності й активності, у той час як промисловості були потрібні кваліфіковані робітники, здатні впоратися зі складним технічним устаткуванням. Формалізм і вербалізм традиційного навчання позначалися в тому, що випускники не були готові застосувати отримані теоретичні знання на практиці [3].

Отже, поява освітніх реформаторських течій наприкінці XIX - початку XX ст. у Свропі зумовлена прагненням педагогів побудувати нову школу на теоретичних засадах педагогів-класиків. Реформаторські течії визначалися негативним ставленням до традиційної теорії і практики навчання і виховання, глибокою повагою й інтересом до особистості дитини, новими шляхами розв'язання педагогічних проблем, 3-поміж яких пошук шляхів становлення особистості протягом періоду дитинства, розвиток творчих сил, обов'язковість іiі особистого самоусвідомлення, здатність до соціальної адаптації тощо. Головною метою реформаторів стали модернізація та модифікація традиційної школи, засобом розроблення і впровадження основних концептуальних положень (ідея організації діяльності задля забезпечення саморозвитку особистості). Характерною ознакою нових освітніх течій було поєднання теоретичних інноваційних пропозицій із практичною діяльністю.

\section{Література}

1. Джуринский А. Н. Размышления над историей педагогики / А. Н. Джуринский // Педагогика. - 2001. - № 6. - С. 72-80. 2. Катков М. Н. Наша учебная реформа с примечаниями Л. Поливанова / М. Н. Катков. - М. : [б.и.], 1890. - 48 с. 3. Козлова Г. Н. Воспитание в отечественной общеобразовательной средней школе: цели, сфера действия, результаты : [монографія] / предисловие А. А. Фролова / Г. Н. Козлова. - Н. Новгород: Изд. НГПУ, 1999. - 297 с. 4. Константинов Н. А. Очерки по истории средней школы / Н. А. Константинов. М. : Учпедгиз, 1947. - 247 с. 5. Энциклопедия общественного воспитания и обучения. - СПб. - М. : Изд-во М. О. Вольф, 1913. - 67 с. 